Article

\title{
Trends in the Epidemiology and Outcomes of Pneumocystis Pneumonia among Human Immunodeficiency Virus (HIV) Hospitalizations
}

\author{
Kalaimani Elango ${ }^{1,+} \mathbb{D}$, Mayuri Mudgal ${ }^{2,+}$, Swetha Murthi ${ }^{3}$, Prashanth Reddy Yella ${ }^{4} \mathbb{D}$, Savan Nagrecha ${ }^{5}$, \\ Vedhapriya Srinivasan ${ }^{6}$, Vijaykumar Sekar ${ }^{7}$, Maria Koshy ${ }^{8}$, Sathishkumar Ramalingam ${ }^{9}$ and \\ Kulothungan Gunasekaran 10,*(D)
}

Citation: Elango, K.; Mudgal, M.; Murthi, S.; Yella, P.R.; Nagrecha, S.; Srinivasan, V.; Sekar, V.; Koshy, M.; Ramalingam, S.; Gunasekaran, K. Trends in the Epidemiology and Outcomes of Pneumocystis Pneumonia among Human Immunodeficiency Virus (HIV) Hospitalizations. Int. J. Environ. Res. Public Health 2022, 19, 2768. https:// doi.org/10.3390/ijerph19052768

Academic Editor: Paul B. Tchounwou

Received: 27 January 2022

Accepted: 24 February 2022

Published: 27 February 2022

Publisher's Note: MDPI stays neutral with regard to jurisdictional claims in published maps and institutional affiliations.

Copyright: (C) 2022 by the authors. Licensee MDPI, Basel, Switzerland. This article is an open access article distributed under the terms and conditions of the Creative Commons Attribution (CC BY) license (https:// creativecommons.org/licenses/by/ $4.0 /)$.
1 Division of Cardiology, University of Nevada, 4505 S Maryland Pkwy, Las Vegas, NV 89154, USA; kalaimani.elango@gmail.com

2 Department of Geriatric Medicine, Montefiore Medical Center, Wakefield Campus, 600 E 233rd Street Bronx, New York, NY 10466, USA; mayurimudgal@gmail.com

3 Department of Endocrinology, Yuma Regional Medical Center, 2400 S Avenue A, Yuma, AZ 85364, USA; drswethamurthi@gmail.com

4 Department of Internal Medicine, Yuma Regional Medical Center, 2400 S Avenue A, Yuma, AZ 85364, USA; prashanthreddy2179@gmail.com

5 Department of Pharmacy, Yuma Regional Medical Center, 2400 S Avenue A, Yuma, AZ 85364, USA; savanrx@gmail.com

6 Department of Internal Medicine, Suny Downstate Medical Center, New York, NY 11203, USA; vedhavimal612@gmail.com

7 Department of Endocrinology, Lehigh Valley Health Center, 1243 S Cedar Crest Blvd, Allentown, PA 18103, USA; medvijay1983@gmail.com

8 Department of Internal Medicine, Bridgeport Hospital, 267 Grant Street, Bridgeport, CT 06610, USA; shrutikoshy@gmail.com

9 Department of Internal Medicine, Lovelace Medical Center, 601 Dr. Martin Luther King Jr. Avenue NE, Albuquerque, NM 87102, USA; sathishmed@gmail.com

10 Department of Pulmonary Diseases and Critical Care, Yuma Regional Medical Center, 2400 S Avenue A, Yuma, AZ 85364, USA

* Correspondence: stankuloth@gmail.com; Tel.: +1-928-336-2434

$+\quad$ These authors contributed equally to this work.

\begin{abstract}
Introduction: Pneumocystis Pneumonia (PCP) is a common opportunistic infection among people living with the human immunodeficiency virus (HIV). This study's objective was to assess temporal trends in PCP epidemiology among hospitalized patients with HIV/AIDS in the US and to compare data for hospitalizations with HIV with PCP to those without PCP. Methods: The national inpatient sample (NIS) data were analyzed from 2002-2014. The discharge coding identified hospitalized patients with HIV or AIDS and with or without PCP. Results: We identified 3,011,725 hospitalizations with HIV / AIDS during the study period; PCP was present in 5\% of the patients with a diagnosis of HIV. The rates of PCP progressively declined from $6.7 \%$ in 2002 to $3.5 \%$ in 2014 $(p<0.001)$. Overall mortality in patients with HIV was 3.3\% and was significantly higher in those with PCP than without PCP $(9.9 \%$ vs. $2.9 \% ; p<0.001)$. After adjusting for demographics and other comorbidities, PCP had higher odds of hospital mortality 3.082 (OR 3.082; 95\% CI, 3.007 to 3.159; $p<0.001$ ). Conclusion: From 2002 to 2014, the rate of PCP in HIV patients has decreased significantly in the United States but is associated with substantially higher mortality.
\end{abstract}

Keywords: Pneumocystis pneumonia; PCP; human immunodeficiency virus; HIV; epidemiology; Pneumocystis jirovecii; opportunistic infection; antiretroviral therapy; pneumonia

\section{Introduction}

Human immunodeficiency virus (HIV)/acquired immune-deficiency syndrome (AIDS) continues to be a significant health burden with around 36 million people worldwide $[1,2]$. 
Of this, approximately 1.2 million HIV-positive people reside in USA [3]. Pneumocystis pneumonia has long been known to be a significant health concern in this sub-population.

A fungus, Pneumocystis jirovecii, causes Pneumocystis pneumonia (PCP). With changes in the taxonomy, Pneumocystis carinii now denotes Pneumocystis that infects rats, and $P$. jirovecii denotes the species that infects humans.

Before early 1980s, Pneumocystis carini pneumonia (PCP) was a rare but fatal infection that occurred in immune-compromised patients with hematopoietic cancers (predominantly, acute lymphocytic leukemia), those with protein energy malnutrition, or in patients receiving corticosteroid therapy. In 1981, a report of five cases of Pneumocystis carinii pneumonia (PCP) among previously healthy homosexual young men in Los Angeles was noted [4]. This first identified the initial signs of the acquired immunodeficiency syndrome (AIDS) epidemic in HIV patients.

Approximately $90 \%$ of PCP cases occurred in patients with CD4 T lymphocyte (CD4) cell counts $<200$ cells $/ \mathrm{mm}^{3}$. Other risk factors for PCP in the pre-ART (Anti-retroviral therapy) era were CD4 cell percentage $<14 \%$, previous episodes of $\mathrm{PCP}$, oral thrush, recurrent bacterial pneumonia, unintentional weight loss, and higher plasma HIV RNA levels [5,6].

The clinical triad of PCP includes subacute onset of progressive dyspnea, fever, and a non-productive cough. There is chest discomfort that worsens within days to weeks [7].

The earlier diagnosis of HIV, antiretroviral therapy, and effective prophylaxis have all contributed to a 75\% decline in PCP cases [8]. However, the rates of hospitalization among HIV-positive persons continue to remain higher than that of the general population $[9,10]$.

In one study, HIV-infected patients with PCP had a significantly greater number of organisms and fewer neutrophils in bronchoalveolar lavage (BAL) fluid, and less severe oxygenation impairment compared to other immunocompromised patients with PCP. This proposed that the severity of PCP could be determined by the inflammatory response rather than by the load of the organism itself [11]. Other studies have compared PCP features and outcomes in HIV versus non-HIV patients suggesting increased requirement of intensive care or ventilation, and the rate of in-hospital deaths [12,13]. We aim to determine the impact of PCP on patients with HIV admitted to the hospital and assess temporal trends in the patients with PCP versus those without PCP.

\section{Materials and Methods}

\subsection{Data Source and Study Design}

This study was a retrospective cross-sectional study of all hospital admissions with a primary discharge diagnosis of human immunodeficiency virus (HIV) between 2002 and 2014. We examined the trends in the epidemiology and outcomes of Pneumocystis pneumonia (PCP) among HIV hospitalizations using discharge data from the National Inpatient Sample (NIS), the Healthcare Cost and Utilization Project (HCUP), and the Agency for Healthcare Research and Quality [14]. As the largest publicly available allpayer inpatient healthcare database in the USA, the NIS provides national estimates of more than 7 million discharges per annum. NIS is a self-weighted, stratified, systematic, random sample of $20 \%$ discharges from all non-federal US community hospitals (prior to 2012 , it was a $20 \%$ sample of hospitals from which all discharges were retained). To account for this redesign, the trend weight (TRENDWT) provided by HCUP is used in place of original discharge weight (DISCWT) to create national estimates for years prior to 2012 [15]. The NIS sample is stratified on hospital characteristics. This form of clustering tends to induce dependence among discharges within hospitals; hence, variance analysis of subsets in line with NIS methods was performed [16]. The diagnoses and procedures were encoded with the International Classification of Diseases, Ninth Revision, Clinical Modification (ICD-9-CM). Since this study included deidentified data, per the data use agreement with the Agency for Healthcare Research and Quality, the institutional review board requirement was waived. Hospital charges were included as "Total charges" incurred during the admission as provided by the NIS database. 


\subsection{Study Groups and Outcomes}

We used ICD-9-CM codes to identify all hospitalized adults (aged $\geq 18$ years), who had a primary diagnosis of HIV or AIDS (ICD-9-CM diagnosis codes $042 \times, 043 \times, 044 \times$, 079.53, 795.71, V08, V65, 44,042.9) between January 2002 and December 2014. Those with missing data for gender, mortality, and length of stay were excluded. Dummy cases with hospital identifiers were added to make sure all the hospitals in the US irrespective of HIV diagnosis were added to the analysis to account for the complex sampling design of the NIS database given the clustering effect.

Among HIV / AIDS admissions, those with PCP were extracted using ICD-9 CM diagnosis code 136.3 from the secondary diagnoses. NIS provides 29 comorbidities (also known as Elixhauser comorbidity measures) based on ICD-9 CM diagnoses and the diagnosisrelated group in effect on the date of discharge. These comorbidities are not directly related to the principal diagnosis or the main reason for admission and are likely to have originated before the hospital stay [17].

The primary outcome of interest was the trends in the prevalence and outcomes such as hospital length of stay, and in-hospital mortality among 2 subgroups of HIV, such as HIV with PCP, and HIV with no PCP.

\subsection{Statistical Analyses}

We adhered to the methodological standards described by Khera et al. [18]. All data analyses were performed using IBM SPSS Statistics for Windows, version 24.0 (IBM, Armonk, NY, USA). The study analysis was performed using the complex sample analysis method accounting for the clustering effect of the sample design. Weight was applied to obtain national estimates. Continuous values are reported as mean \pm standard error of the mean and compared using analysis of variance (ANOVA). Categorical variables were reported as a number and/or percentage and compared using the chi-squared test. Multivariable logistic regression analyses were performed while accounting for the sampling technique and adjusting for various demographic variables, clinical variables, and hospital characteristics.

\section{Results}

\subsection{PCP Incidence, Demographic Characteristics and Prevelance}

From January 2002 to December 2014, there were an estimated 3,011,725 hospitalizations with HIV / AIDS. Out of these, 148,624 patients (5\%) had PCP and 2,863,099 patients (95\%) did not have PCP. The mean age for HIV patients with PCP was $42 \pm 10$ years and without PCP was $45 \pm 11$ years. Among HIV hospitalizations, males had a higher prevalence of PCP compared to females (70\% vs. 30\%, $p<0.0001)$. The majority of HIV hospitalizations with and without PCP were Blacks (52.7\% and 53.3\% respectively) followed by Caucasians (27.9\% and $24.8 \%$ respectively) followed by Hispanics (13.8\% and $12.3 \%$ respectively). The mean LOS in days was lower in HIV hospitalizations without PCP (6.33 vs. 10.59, $p<0.0001)$, suggesting a longer hospital stay in HIV patients with PCP. The majority of the HIV hospitalizations both with PCP and without PCP were in an urban setting $(96.5 \%$ vs. $3.5 \%, p<0.0001)$ (Table 1$)$. Over a period of 13 years, we noted a progressive decline in rates of PCP among HIV hospitalizations from $6.7 \%$ in 2002 to $3.5 \%$ in $2014(p<0.0001)$ (Table 2 and Figure 1).

Multivariate logistic regression analyses were performed. In the multivariate analysis, prevalence, length of stay and in-hospital mortality were analyzed. All models were adjusted for age, gender, race, comorbidities, residential region, hospital size, location/teaching status of the hospital, and median household income (Table 1). 
Table 1. Demographic characteristics of HIV hospitalizations with and without Pneumocystis pneumonia (PCP).

\begin{tabular}{|c|c|c|c|c|}
\hline Clinical Characteristics & All HIV $(n=3,011,724)$ & $\begin{array}{l}\text { HIV without PCP } \\
\quad(n=2,863,099)\end{array}$ & $\begin{array}{l}\text { HIV with PCP } \\
(n=148,624)\end{array}$ & $p$-Value \\
\hline Age & $45.18 \pm 11.109$ & $45.35 \pm 11.133$ & $42.08 \pm 10.141$ & $<0.0001$ \\
\hline Length of stay & $6.54 \pm 8.938$ & $6.33 \pm 8.742$ & $10.59 \pm 11.378$ & $<0.0001$ \\
\hline Total charges & $38,243.79 \pm 66,337$ & $36,860.45 \pm 63,561$ & $65,090.83 \pm 103,153$ & $<0.0001$ \\
\hline $\begin{array}{c}\text { Sex } \\
\text { Male } \\
\text { Female }\end{array}$ & $\begin{array}{l}1,981,195(65.8 \%) \\
1,030,528(34.2 \%)\end{array}$ & $\begin{array}{c}1,876,654(65.5 \%) \\
986,446(34.5 \%)\end{array}$ & $\begin{array}{c}104,542(70.3 \%) \\
44,083(29.7 \%)\end{array}$ & $\begin{array}{l}<0.0001 \\
<0.0001\end{array}$ \\
\hline $\begin{array}{c}\text { Race (uniform) } \\
\text { White } \\
\text { Black } \\
\text { Hispanic } \\
\text { Asian or Pacific Islander } \\
\text { Native American } \\
\text { Others }\end{array}$ & $\begin{array}{c}745,951(24.8 \%) \\
1,426,627(47.4 \%) \\
370,092(12.3 \%) \\
15,160(0.5 \%) \\
9370(0.3 \%) \\
108,755(3.6 \%)\end{array}$ & $\begin{array}{c}711,292(27.9 \%) \\
1,358,620(53.3 \%) \\
350,334(13.8 \%) \\
13,781(0.5 \%) \\
8853(0.3 \%) \\
103,914(4.1 \%)\end{array}$ & $\begin{array}{c}34,659(26.8 \%) \\
68,006(52.7 \%) \\
19,758(15.3 \%) \\
1379(1.1 \%) \\
517(0.4 \%) \\
4841(3.7 \%)\end{array}$ & $\begin{array}{l}<0.0001 \\
<0.0001 \\
<0.0001 \\
<0.0001 \\
<0.0001 \\
<0.0001\end{array}$ \\
\hline $\begin{array}{c}\text { Region of Hospital } \\
\text { Northeast } \\
\text { Midwest or North Central } \\
\text { South } \\
\text { West } \\
\text { Died } \\
\text { Admission day is a weekend }\end{array}$ & $\begin{array}{c}991,494(32.9 \%) \\
367,812(12.2 \%) \\
1344,453(44.6 \%) \\
307,964(10.2 \%) \\
98,361(3.3 \%) \\
634,783(21.1 \%)\end{array}$ & $\begin{array}{c}957,493(33.4 \%) \\
352,235(12.3 \%) \\
1,265,753(44.2 \%) \\
287,618(10 \%) \\
83,666(2.9 \%) \\
601,454(21 \%)\end{array}$ & $\begin{array}{c}34,001(22.9 \%) \\
15,577(10.5 \%) \\
78,701(53 \%) \\
20,346(13.7 \%) \\
14,695(9.9 \%) \\
33,328(22.4 \%)\end{array}$ & $\begin{array}{l}<0.0001 \\
<0.0001 \\
<0.0001 \\
<0.0001 \\
<0.0001 \\
<0.0001\end{array}$ \\
\hline $\begin{array}{c}\text { Disposition of patient (uniform) } \\
\text { Routine } \\
\text { Short-term hospital } \\
\text { Skilled Nursing Facility (SNF) } \\
\text { Intermediate Care Facility (ICF) } \\
\text { Another type of facility } \\
\text { Home Health Care (HHC) } \\
\text { Against medical advice (AMA) } \\
\text { Elective admission }\end{array}$ & $\begin{array}{c}2,108,095(70 \%) \\
53,929(1.8 \%) \\
332,526(11 \%) \\
252,057(8.4 \%) \\
165,155(5.5 \%) \\
98,361(3.3 \%) \\
1600(0.1 \%) \\
352,729(11.7 \%)\end{array}$ & $\begin{array}{c}2,008,111(70.1 \%) \\
51,218(1.8 \%) \\
318,668(11.1 \%) \\
241,519(8.4 \%) \\
158,414(5.5 \%) \\
83,666(2.9 \%) \\
1503(0.1 \%) \\
345,138(12.1 \%)\end{array}$ & $\begin{array}{c}99,984(67.3 \%) \\
2712(1.8 \%) \\
13,858(9.3 \%) \\
10,538(7.1 \%) \\
6741(4.5 \%) \\
14,695(9.9 \%) \\
97(0.1 \%) \\
7591(5.1 \%)\end{array}$ & $\begin{array}{l}<0.0001 \\
<0.0001 \\
<0.0001 \\
<0.0001 \\
<0.0001 \\
<0.0001 \\
<0.0001 \\
<0.0001\end{array}$ \\
\hline $\begin{array}{c}\text { Primary expected payer (uniform) } \\
\text { Medicare } \\
\text { Medicaid } \\
\text { Private insurance } \\
\text { Self-pay } \\
\text { No charge } \\
\text { Other }\end{array}$ & $\begin{array}{c}878,453(29.2 \%) \\
1,222,318(40.6 \%) \\
484,582(16.1 \%) \\
267,607(8.9 \%) \\
40,276(1.3 \%) \\
109,624(3.6 \%)\end{array}$ & $\begin{array}{c}853,848(29.9 \%) \\
1,164,708(40.8 \%) \\
451,652(15.8 \%) \\
245,845(8.6 \%) \\
37,399(1.3 \%) \\
101,666(3.6 \%)\end{array}$ & $\begin{array}{c}24,604(16.7 \%) \\
57,610(39 \%) \\
32,930(22.3 \%) \\
21,761(14.7 \%) \\
2877(1.9 \%) \\
7958(5.4 \%)\end{array}$ & $\begin{array}{l}<0.0001 \\
<0.0001 \\
<0.0001 \\
<0.0001 \\
<0.0001 \\
<0.0001\end{array}$ \\
\hline $\begin{array}{l}\text { Median household income quartile for } \\
\text { patient's ZIP Code } \\
\text { 0-25th percentile } \\
\text { 26th to 50th percentile (median) } \\
\text { 51st to 75th percentile } \\
\text { 76th to 100th percentile }\end{array}$ & $\begin{array}{c}1,298,141(43.1 \%) \\
603,834(20 \%) \\
446,650(14.8 \%) \\
280,062(9.3 \%)\end{array}$ & $\begin{array}{c}1,233,011(49.5 \%) \\
572,324(23 \%) \\
422,667(17 \%) \\
265,201(10.6 \%)\end{array}$ & $\begin{array}{c}65,130(48.1 \%) \\
31,510(23.3 \%) \\
23,983(17.7 \%) \\
14,861(11 \%)\end{array}$ & $\begin{array}{l}<0.0001 \\
<0.0001 \\
<0.0001 \\
<0.0001\end{array}$ \\
\hline $\begin{array}{c}\text { Bed size of hospital } \\
\text { Small } \\
\text { Medium } \\
\text { Large }\end{array}$ & $\begin{array}{c}273,420(9.1 \%) \\
748,044(24.8 \%) \\
1,979,628(65.7 \%)\end{array}$ & $\begin{array}{c}261,546(9.2 \%) \\
710,475(24.9 \%) \\
1,880,911(65.9 \%)\end{array}$ & $\begin{array}{c}11,873(8 \%) \\
37,569(25.4 \%) \\
98,718(66.6 \%)\end{array}$ & $\begin{array}{l}<0.0001 \\
<0.0001 \\
<0.0001\end{array}$ \\
\hline $\begin{array}{c}\text { Control/ownership of hospital } \\
\text { Government or private (collapsed category) } \\
\text { Government, nonfederal (public) } \\
\text { Private, not-for-profit (voluntary) } \\
\text { Private, investor-owned (proprietary) } \\
\text { Private (collapsed category) }\end{array}$ & $\begin{array}{c}1,825,278(60.6 \%) \\
113,581(3.8 \%) \\
234,390(7.8 \%) \\
172,701(5.7 \%) \\
11,387(0.4 \%)\end{array}$ & $\begin{array}{c}1,732,348(77.6 \%) \\
106,306(4.8 \%) \\
219,797(9.8 \%) \\
163,042(7.3 \%) \\
10,929(0.5 \%)\end{array}$ & $\begin{array}{c}92,930(74.4 \%) \\
7275(5.8 \%) \\
14,593(11.7 \%) \\
9658(7.7 \%) \\
458(0.4 \%)\end{array}$ & $\begin{array}{l}<0.0001 \\
<0.0001 \\
<0.0001 \\
<0.0001 \\
<0.0001\end{array}$ \\
\hline
\end{tabular}


Table 1. Cont.

\begin{tabular}{|c|c|c|c|c|}
\hline Clinical Characteristics & All HIV $(n=3,011,724)$ & $\begin{array}{l}\text { HIV without PCP } \\
\quad(n=2,863,099)\end{array}$ & $\begin{array}{l}\text { HIV with PCP } \\
(n=148,624)\end{array}$ & $p$-Value \\
\hline \multicolumn{5}{|l|}{ Location/teaching status of hospital } \\
\hline Rural & $103,534(3.4 \%)$ & $98,666(3.5 \%)$ & $4869(3.3 \%)$ & $<0.0001$ \\
\hline Urban nonteaching & $803,918(26.7 \%)$ & $762,579(26.7 \%)$ & $41,338(27.9 \%)$ & $<0.0001$ \\
\hline Urban teaching & $2,093,640(69.5 \%)$ & $1,991,687(69.8 \%)$ & $101,953(68.8 \%)$ & $<0.0001$ \\
\hline Alcohol abuse & $278,873(9.3 \%)$ & $269,281(9.5 \%)$ & $9592(6.5 \%)$ & $<0.0001$ \\
\hline Deficiency anemias & $670,353(22.3 \%)$ & $622,040(21.9 \%)$ & $48,314(32.7 \%)$ & $<0.0001$ \\
\hline $\begin{array}{c}\text { Rheumatoid arthritis/collagen vascular } \\
\text { diseases }\end{array}$ & $20,064(0.7 \%)$ & $19,553(0.7 \%)$ & $512(0.3 \%)$ & $<0.0001$ \\
\hline Chronic blood loss anemia & $37,557(1.2 \%)$ & $36,512(1.3 \%)$ & $1045(0.7 \%)$ & $<0.0001$ \\
\hline Congestive heart failure & $141,072(4.7 \%)$ & $134,102(4.7 \%)$ & $6970(4.7 \%)$ & $<0.0001$ \\
\hline Chronic pulmonary disease & $536,730(17.8 \%)$ & $508,861(17.9 \%)$ & $27,869(18.9 \%)$ & $<0.0001$ \\
\hline Coagulopathy & $226,624(7.5 \%)$ & $215,079(7.6 \%)$ & $11,544(7.8 \%)$ & $<0.0001$ \\
\hline Depression & $323,648(10.7 \%)$ & $311,747(11 \%)$ & $11,901(8.1 \%)$ & $<0.0001$ \\
\hline Diabetes, uncomplicated & $324,690(10.8 \%)$ & $315,834(11.1 \%)$ & $8855(6 \%)$ & $<0.0001$ \\
\hline Diabetes with chronic complications & $65,236(2.2 \%)$ & $63,743(2.2 \%)$ & $1493(1 \%)$ & $<0.0001$ \\
\hline Drug abuse & $640,836(21.3 \%)$ & $615,264(21.6 \%)$ & $25,572(17.3 \%)$ & $<0.0001$ \\
\hline Hypertension & $935,590(31.1 \%)$ & $909,666(32 \%)$ & $25,924(17.5 \%)$ & $<0.0001$ \\
\hline Hypothyroidism & $81,825(2.7 \%)$ & $79,423(2.8 \%)$ & $2403(1.6 \%)$ & $<0.0001$ \\
\hline Liver disease & $351,442(11.7 \%)$ & $339,904(11.9 \%)$ & $11,538(7.8 \%)$ & $<0.0001$ \\
\hline Lymphoma & $74,646(2.5 \%)$ & $72,198(2.5 \%)$ & $2448(1.7 \%)$ & $<0.0001$ \\
\hline Fluid and electrolyte disorders & $815,607(27.1 \%)$ & $752,205(26.4 \%)$ & $63,402(42.9 \%)$ & $<0.0001$ \\
\hline Metastatic cancer & $31,004(1 \%)$ & $30,498(1.1 \%)$ & $506(0.3 \%)$ & $<0.0001$ \\
\hline Other neurological disorders & $237,746(7.9 \%)$ & $230,051(8.1 \%)$ & $7695(5.2 \%)$ & $<0.0001$ \\
\hline Obesity & $101,271(3.4 \%)$ & $98,513(3.5 \%)$ & $2758(1.9 \%)$ & $<0.0001$ \\
\hline Paralysis & $56,265(1.9 \%)$ & $55,135(1.9 \%)$ & $1130(0.8 \%)$ & $<0.0001$ \\
\hline Peripheral vascular disorders & $47,390(1.6 \%)$ & $46,691(1.6 \%)$ & $699(0.5 \%)$ & $<0.0001$ \\
\hline Psychoses & $248,541(8.3 \%)$ & $240,240(8.4 \%)$ & $8301(5.6 \%)$ & $<0.0001$ \\
\hline Pulmonary circulation disorders & $40,013(1.3 \%)$ & $37,177(1.3 \%)$ & $2835(1.9 \%)$ & $<0.0001$ \\
\hline Renal failure & $361,463(12 \%)$ & $351,618(12.4 \%)$ & $9845(6.7 \%)$ & $<0.0001$ \\
\hline Solid tumor without metastasis & $44,766(1.5 \%)$ & $43,738(1.5 \%)$ & $1028(0.7 \%)$ & $<0.0001$ \\
\hline Peptic ulcer disease excluding bleeding & $2417(0.1 \%)$ & $2301(0.1 \%)$ & $116(0.1 \%)$ & $<0.0001$ \\
\hline Valvular disease & $48,602(1.6 \%)$ & $46,589(1.6 \%)$ & $2013(1.4 \%)$ & $<0.0001$ \\
\hline Weight loss & $218,633(7.3 \%)$ & $194,137(6.8 \%)$ & $24,496(16.6 \%)$ & $<0.0001$ \\
\hline
\end{tabular}

Table 2. Trends of hospitalization for HIV and Pneumocystis pneumonia in HIV 2002-2014.

\begin{tabular}{ccc}
\hline Calendar Year & $\begin{array}{c}\text { Total Number of HIV } \\
\text { Hospitalizations }\end{array}$ & $\begin{array}{c}\text { Total Number of HIV } \\
\text { Hospitalizations with PCP }\end{array}$ \\
\hline 2002 & 225,202 & 15,144 \\
\hline 2003 & 220,627 & 14,682 \\
\hline 2004 & 248,090 & 14,006 \\
\hline 2005 & 229,448 & 13,982 \\
\hline 2006 & 253,354 & 13,535 \\
\hline 2007 & 233,297 & 12,489 \\
\hline 2008 & 228,136 & 11,138 \\
\hline 2009 & 243,649 & 10,342 \\
\hline 2010 & 257,093 & 10,820 \\
\hline 2011 & 229,071 & 9240 \\
\hline 2012 & 216,110 & 7800 \\
\hline 2013 & 214,685 & 7780 \\
\hline 2014 & 212,960 & 7665 \\
\hline
\end{tabular}




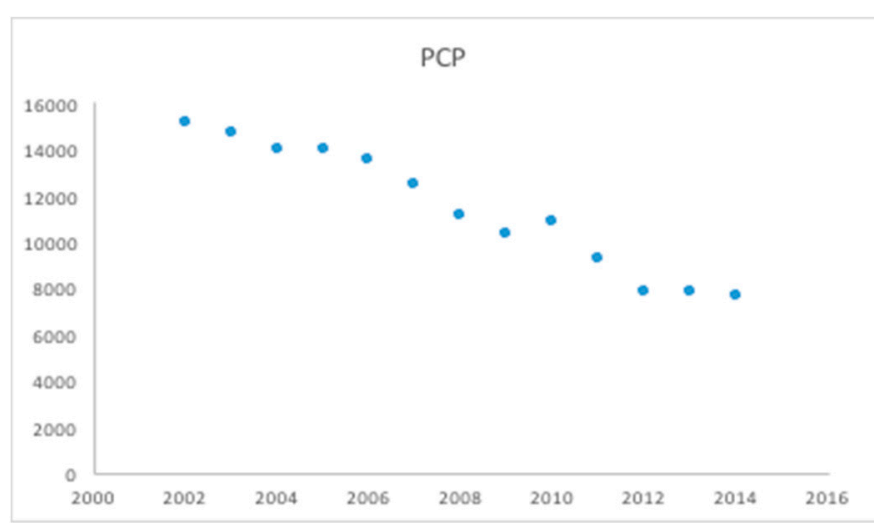

(a)

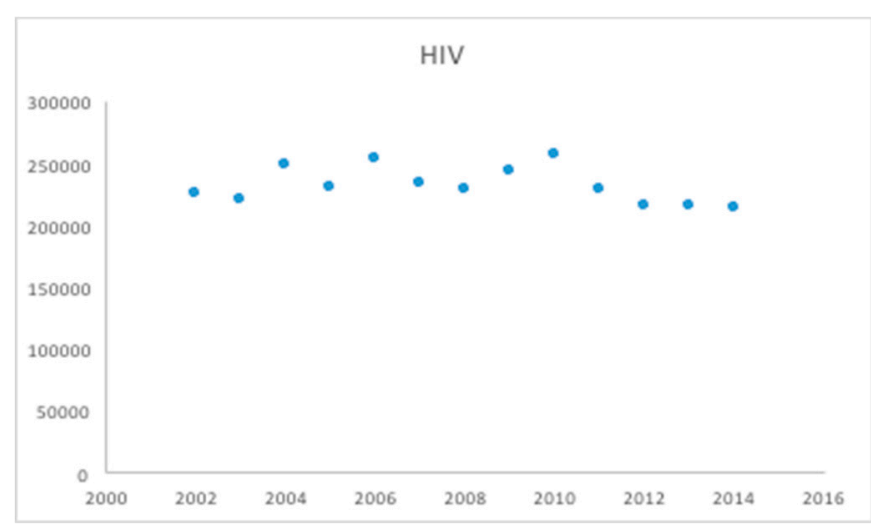

(b)

Figure 1. Trends of hospitalization Pneumocystis pneumonia in HIV (a) and HIV admissions in general (b) 2002-2014.

\subsection{Prevalence}

Our study results show that the prevalence of PCP in patients with HIV hospitalizations declined over the period of 13 years (Table 2 and Figure 1). HIV patients with chronic pulmonary disease, deficiency anemias, fluid and electrolyte disorders, and weight loss had a higher prevalence of PCP compared to HIV patients with other comorbidities (Table 1).

\subsection{Length of Stay Outcome}

The mean length of stay for all HIV hospitalizations was $6.54 \pm 8.93$ days. When length of stay was compared among the groups, HIV patients with PCP had a longer hospital stay than HIV patients without PCP $(10.59$ vs. $6.33, p<0.0001)$. This was evident in the total charges incurred during the hospital stay among the patient population. Those patients without PCP had a total cost of about $\$ 36,860.45$. This was much lower than the total charges incurred for the HIV patients with PCP which was about $\$ 65,090.83(p<0.0001)$ (Table 1).

\subsection{In-Hospital Mortality Outcome}

Overall, in-hospital mortality in patients with HIV was 3.3\% and was significantly higher in HIV patients with PCP than without PCP $(9.9 \%$ vs. $2.9 \% ; p<0.001)$ (Table 1$)$. After adjusting for demographics and other comorbidities, PCP was associated with higher odds of hospital mortality 3.082 (OR 3.082, [95\% confidence interval, CI: 3.007 to 3.159]; $p<0.001$ ) among HIV hospitalizations. Among the other comorbidities, congestive heart failure, coagulopathy, liver disease, lymphoma, fluid, and electrolyte disorders, metastatic cancer, pulmonary circulation disorders, renal failure, solid tumors, and weight loss were associated with higher odds of in-hospital mortality among HIV patients (Table 3). Urban teaching and large-sized hospitals were associated with higher odds of mortality when compared to rural (OR 1.081 [95\% CI: 1.044-1.120]; $p<0.0001$ ) and small-sized hospitals (OR 1.038 [95\% CI: 1.018-1.058]; $p<0.0001$ ), respectively (Table 3). Interestingly, the percentage of in-hospital mortality in HIV patients with PCP declined every year from 2002 to 2014 $(11.5 \%$ to $8.4 \%)$ (Table 4$)$. 
Table 3. Multivariate logistic regression analysis showing the adjusted odds ratios predicting the in-hospital mortality for HIV hospitalizations.

\begin{tabular}{|c|c|c|c|c|}
\hline HIV Patients with Comorbidities & $\begin{array}{l}\text { Odds Ratio for } \\
\text { Mortality }\end{array}$ & \multicolumn{2}{|c|}{ 95\% Confidence Interval } & \multirow{2}{*}{$\begin{array}{c}p \text {-Value } \\
<0.0001\end{array}$} \\
\hline Pneumocystis pneumonia & 3.082 & 3.007 & 3.159 & \\
\hline Alcohol abuse & 0.799 & 0.773 & 0.827 & $<0.0001$ \\
\hline Deficiency anemias & 0.715 & 0.701 & 0.73 & $<0.0001$ \\
\hline $\begin{array}{l}\text { Rheumatoid arthritis/collagen } \\
\text { vascular diseases }\end{array}$ & 0.86 & 0.759 & 0.975 & $<0.0001$ \\
\hline Chronic blood loss anemia & 1.054 & 0.984 & 1.129 & $<0.0001$ \\
\hline Congestive heart failure & 1.834 & 1.778 & 1.892 & $<0.0001$ \\
\hline Chronic pulmonary disease & 0.789 & 0.77 & 0.809 & $<0.0001$ \\
\hline Coagulopathy & 3.54 & 3.467 & 3.615 & $<0.0001$ \\
\hline Depression & 0.551 & 0.531 & 0.572 & $<0.0001$ \\
\hline Diabetes, uncomplicated & 0.897 & 0.871 & 0.924 & $<0.0001$ \\
\hline $\begin{array}{l}\text { Diabetes with chronic } \\
\text { complications }\end{array}$ & 0.786 & 0.74 & 0.835 & $<0.0001$ \\
\hline Drug abuse & 0.679 & 0.663 & 0.696 & $<0.0001$ \\
\hline Hypertension & 0.675 & 0.66 & 0.69 & $<0.0001$ \\
\hline Hypothyroidism & 0.97 & 0.919 & 1.023 & $<0.0001$ \\
\hline Liver disease & 1.388 & 1.356 & 1.421 & $<0.0001$ \\
\hline Lymphoma & 2.574 & 2.485 & 2.667 & $<0.0001$ \\
\hline Fluid and electrolyte disorders & 2.904 & 2.854 & 2.955 & $<0.0001$ \\
\hline Metastatic cancer & 3.787 & 3.601 & 3.983 & $<0.0001$ \\
\hline Other neurological disorders & 1.845 & 1.799 & 1.893 & $<0.0001$ \\
\hline Obesity & 0.651 & 0.604 & 0.702 & $<0.0001$ \\
\hline Paralysis & 1.357 & 1.284 & 1.434 & $<0.0001$ \\
\hline Peripheral vascular disorders & 1.256 & 1.177 & 1.342 & $<0.0001$ \\
\hline Psychoses & 0.653 & 0.627 & 0.68 & $<0.0001$ \\
\hline Pulmonary circulation disorders & 1.811 & 1.711 & 1.916 & $<0.0001$ \\
\hline Renal failure & 1.811 & 1.766 & 1.856 & $<0.0001$ \\
\hline Solid tumor without metastasis & 1.657 & 1.567 & 1.752 & $<0.0001$ \\
\hline $\begin{array}{l}\text { Peptic ulcer disease excluding } \\
\text { bleeding }\end{array}$ & 0.828 & 0.648 & 1.058 & $<0.0001$ \\
\hline Valvular disease & 1.027 & 0.971 & 1.086 & $<0.0001$ \\
\hline Weight loss & 1.873 & 1.829 & 1.918 & $<0.0001$ \\
\hline
\end{tabular}

Table 4. Trends of mortality in HIV patients with PCP from 2002-2014.

\begin{tabular}{ccc}
\hline Calendar Year & Mortality in PCP & Mortality in PCP (\%) \\
\hline 2002 & 1736 & 11.5 \\
2003 & 1572 & 10.7 \\
2004 & 1590 & 11.4 \\
2005 & 1394 & 10 \\
2006 & 1393 & 10.3 \\
2007 & 1126 & 9 \\
2008 & 1153 & 10.4 \\
2009 & 1010 & 9.8 \\
2010 & 945 & 8.7 \\
2011 & 685 & 7.4 \\
2012 & 685 & 8.8 \\
2013 & 760 & 9.8 \\
2014 & 645 & 8.4 \\
\hline
\end{tabular}

\section{Discussion}

Pneumocystis pneumonia (PCP) is an AIDS-defining illness [19]. In the Antiretroviral Therapy Cohort Collaboration, comprised of 15 North American and European cohorts established in 2000, PCP was the second most frequent AIDS-defining diagnosis (first being esophageal candidiasis) [20]. Various studies have noted approximately $23-31 \%$ 
PCP cases occurring in patients who were newly diagnosed with HIV at the time of PCP presentation [21-23]. Other cases occurred with non-adherence to anti-retroviral therapy (ART) or sub-optimal immune recovery [24]. Another study from Spain noted an increase in the proportion of patients with PCP, before being diagnosed with HIV, from $48 \%$ in 2000 to $67 \%$ in 2013 [25]. PCP, therefore, continues to remain an important health concern in patients with HIV.

Our study noted a decline in PCP prevalence amongst HIV patients from $6.7 \%$ in 2002 to $3.5 \%$ in 2014 with a cumulative prevalence of 5\%. A similar trend was demonstrated by the Centers for Disease Control and Prevention, AIDS Surveillance Summaries, 1989-1992, where the prevalence of PCP in HIV patients was noted at 53\% in 1989 with a subsequent decline to $42 \%$ by 1992 and 3.4\% every year from 1992 [26]. Sub-Saharan studies from 1992-1994 were notable for PCP prevalence of 5-9\%, which was relatively lower compared to developed countries at that time [27-29]. This was noted to be likely secondary to neglected/missed data, as proven by a systematic review and meta-analysis of 48 subSaharan studies. This meta-analysis also noted a decrease in the prevalence of PCP in HIV-infected patients in sub-Saharan Africa between 1995 and 2015 from 28\% to 9\% after 2005 [30].

Of note, prophylaxis against pneumocystis with trimethoprim-sulfamethoxazole was introduced in 1989 [31]. Various trials have noted that this once-a-day pill has been highly effective in the primary prevention as well as treatment for PCP [32,33]. The combined antiretroviral therapy was approved in 1991 when additional nucleoside reverse transcriptase inhibitors (NRTI) were approved by the FDA for HIV infection (NRTI, Zidovudine was approved in 1987) which was followed by approval of the non-nucleoside class of antiretrovirals in 1995, allowing for the possible use of combination antiretrovirals called highly active anti-retroviral therapy (HAART) to treat HIV disease. The Global Burden of Disease [GBD] 2017 HIV collaborators noted that the access to ART from 2.98 million people in 2006 to 21.8 million in 2017 was accompanied by a 51\% reduction in HIV mortality, from 1.95 million in 2006 to 0.95 million in 2017. Interestingly, in 2006, a single-tablet regimen for ART was introduced. This was followed by multiple single-tablet regimens. A 2014 meta-analysis emphasized that better adherence and virological suppression were achieved with this regimen [34].

Similarly, an increased availability and improved adherence as once a day medication of trimethoprim-sulfamethoxazole for PCP prophylaxis and treatment along with singletablet regimen for ART explains that probably fewer HIV patients need to be hospitalized for management of PCP, thus decreasing its prevalence in our study population.

HIV with/without PCP was predominantly common in males with lower median household income and in African American, white, and Hispanic populations in our study. This has also been noted in literature before. This is likely secondary to higher rates of male-to-male sexual contact as well as infrequent HIV testing and late HIV diagnosis among these populations suffering from healthcare disparities [35]. This also corresponds to an increased prevalence of HIV and PCP infections in the southern and northeast regions of USA as noted in our study.

As per Centers for Disease Control and Prevention (CDC), the rates of HIV incidence are highest among ages 25-44 [3]. In one study, approximately $9.4 \%$ of newly diagnosed HIV patients, were more than 55 years of age. Diagnosis delay (time from infection to diagnosis) was longer among persons who were older at diagnosis than among those who were younger (median $=4.5$ years among persons aged $\geq 55$ years compared with 2.4 years among persons aged $13-24$ years $)(p<0.01)$. This meant that older population are more likely to have a higher stage of HIV at the time of diagnosis [36]. Moreover, heterosexual men are more likely than women and men having sex with men to have missed the opportunity for getting tested for HIV therefore having a longer diagnostic delay [37]. Similarly, non-white racial/ethnic groups had higher proportion of infections attributable to heterosexual contact among these groups compared with whites [38]. 
These factors denote that HIV patients with diagnostic delays have a higher immune function damage at the time of diagnosis which increases their morbidity and mortality. Earlier diagnosis along with prompt linkage to health care and initiation of antiretroviral treatment enhances improvement of immune function and viral suppression thereby, reducing risk for sexual transmission of HIV [39].

The in-hospital mortality rate for patients with HIV and PCP has been in the range of $4-32 \%$ [40,41]. In our multi-variate logistic regression analysis adjusting for patient demographics and co-morbidities, there is an increased mortality in HIV patients with PCP compared to HIV without PCP (9.9\% vs. 2.9\%, OR 3.08). Mortality risk factors for HIV patients with PCP have previously been identified and include increasing age, subsequent episodes of PCP, low hemoglobin level, low basal PaO2 at hospital admission, pulmonary Kaposi sarcoma, and pre-existing co-morbidities [3,40]. A study from Taiwan noted three predictors associated with mortality-systolic blood pressure $\leq 110 \mathrm{mmHg}$ [adjusted odds ratio (AOR) 3.88; 95\% confidence interval (CI) 1.17-12.83; $p=0.03$ ], PaO2at room air $\leq 60 \mathrm{mmHg}$ (AOR 4.97; 95\% CI 1.34-18.23; $p=0.01$ ), and lymphocytes $\leq 10 \%$ (AOR 8.19; 95\% CI 1.48-45.36; $p=0.02$ ) [42]. Another study from China noted initial lactate dehydrogenase levels (level more than $495 \mathrm{U} / \mathrm{L}$ with sensitivity and specificity of $70 \%$ ) to be an independent predictor for mortality in this sub-population of patients [43].

Weight loss, congestive heart failure, coagulopathy, metastatic cancer, liver disease, and renal failure were also noted to be associated with increased mortality in our HIV population. Advanced AIDS patients experience significant weight loss, have higher coagulopathy, an increased risk of AIDS related/non-AIDS related cancers, and increased chances of concomitant Hepatitis $C$ infection affecting the liver as well sepsis related renal failure. This is also suggested in prior studies, which noted increased non-AIDS deaths (from non-AIDS infections, cardiovascular, and non-AIDS malignancy) during the HAART era $[44,45]$. It is believed that these are due to complications of aging HIV population, adverse effects of HAART as well as from HIV infection induced unregulated inflammatory response while on HAART accelerating these co-morbidities [46,47].

HIV patients with PCP also have a longer length of stay and higher hospital costs. This is likely because these patients were sicker (possibly due to diffuse alveolar damage due to the host's own inflammatory response causing significant lung injury and defective gas exchange) compared to HIV alone and therefore leading to increased mortality in this sub-population.

The weekend effect, which has been observed with various other medical conditions, was present in this study as well [48-50]. There was an $11 \%$ increase in the risk of weekend mortality compared to weekday mortality in HIV patients with PCP.

\section{Limitations}

Our study has several limitations, some of which are inherent to the analysis of a large administrative database. Since NIS data is based on the discharge diagnosis for identifying patients, and not on individual patients, errors in coding could have led to missing data. The data on the medications, laboratory values are not provided by the database. [50,51] Whether the HIV patients getting hospitalized had already initiated an outpatient prophylaxis / treatment, or had a different inpatient encounter for PCP, could not be ascertained during this admission [50-52]. It is also possible that this subset of hospitalized HIV patients with PCP had failed outpatient empiric antibiotic treatment for other etiologies of pneumonia. Some patients might have had a mild PCP infection not requiring hospitalization. Despite these limitations, this study highlights the prevalence of PCP in HIV patients requiring inpatient treatment and addresses the impact of PCP burden in this subset of hospitalized population.

\section{Conclusions}

In summary, PCP is a life-threatening condition in HIV patients with significantly higher mortality, however, the prevalence of PCP and the mortality from PCP in HIV 
patients have decreased significantly in the HAART era. Our study re-emphasizes the need for early HIV case detection and continued care to prevent morbidity and mortality from AIDS-defining illnesses, specifically PCP.

Author Contributions: Conceptualization, K.G., K.E. and S.M.; methodology, S.M. and K.E.; writingoriginal draft preparation, M.M., S.M., P.R.Y., S.R., M.K. and V.S. (Vedhapriya Srinivasan); writingreview and editing, V.S. (Vijaykumar Sekar), S.N. and K.G.; visualization and supervision, S.R., K.G. and S.M.; project administration, K.G. and K.E. All authors have read and agreed to the published version of the manuscript.

Funding: This research received no external funding.

Institutional Review Board Statement: Ethical review and approval were waived for this study due to the analysis involving only de-identified data.

Informed Consent Statement: Patient consent was waived due to the analysis involving only deidentified data.

Data Availability Statement: The data presented in this study are available on request from the corresponding author.

Conflicts of Interest: The authors declare no conflict of interest.

\section{References}

1. UNAIDS. 90-90-90: Treatment for All. Available online: https://www.unaids.org/en/resources/909090 (accessed on 12 February 2022 ).

2. Frank, T.D.; Carter, A.; Jahagirdar, D.; Biehl, M.H.; Douwes-Schultz, D.; Larson, S.L.; Arora, M.; Dwyer-Lindgren, L.; Steuben, K.M.; Abbastabar, H.; et al. Global, Regional, and National Incidence, Prevalence, and Mortality of HIV, 1980-2017, and Forecasts to 2030, for 195 Countries and Territories: A Systematic Analysis for the Global Burden of Diseases, Injuries, and Risk Factors Study 2017. Lancet HIV 2019, 6, e831-e859. [CrossRef]

3. Centers for Disease Control and Prevention. Centers for Disease Control and Prevention. Estimated HIV Incidence and Prevalence in the United States, 2015-2019. HIV Surveillance Supplemental Report 2021, 26 (No. 1). Published May 2021. Available online: http:/ / www.cdc.gov/hiv/library/reports/hiv-surveillance.html (accessed on 13 February 2022).

4. Pneumocystis Pneumonia_Los Angeles. Available online: https://www.cdc.gov/mmwr/preview/mmwrhtml/june_5.htm (accessed on 12 February 2022).

5. Kaplan, J.E.; Hanson, D.L.; Navin, T.R.; Jones, J.L. Risk Factors for PrimaryPneumocystis CariniiPneumonia in Human Immunodeficiency Virus-Infected Adolescents and Adults in the United States: Reassessment of Indications for Chemoprophylaxis. J. Infect. Dis. 1998, 178, 1126-1132. [CrossRef]

6. Kaplan, J.E.; Hanson, D.L.; Jones, J.L.; Dworkin, M.S. Viral Load as an Independent Risk Factor for Opportunistic Infections in HIV-Infected Adults and Adolescents. AIDS 2001, 15, 1831-1836. [CrossRef]

7. Selwyn, P.A.; Pumerantz, A.S.; Durante, A.; Alcabes, P.G.; Gourevitch, M.N.; Boiselle, P.G.; Elmore, J.G. Clinical Predictors of Pneumocystis Carinii Pneumonia, Bacterial Pneumonia and Tuberculosis in HIV-Infected Patients. AIDS 1998, 12, 885-893. [CrossRef] [PubMed]

8. Palella, F.J.; Delaney, K.M.; Moorman, A.C.; Loveless, M.O.; Fuhrer, J.; Satten, G.A.; Aschman, D.J.; Holmberg, S.D. Declining Morbidity and Mortality among Patients with Advanced Human Immunodeficiency Virus Infection. N. Engl. J. Med. 1998, 338, 853-860. [CrossRef] [PubMed]

9. Crum-Cianflone, N.F.; Grandits, G.; Echols, S.; Ganesan, A.; Landrum, M.; Weintrob, A.; Barthel, R.; Agan, B. Trends and Causes of Hospitalizations among HIV-Infected Persons during the Late HAART Era: What Is the Impact of CD4 Counts and HAART Use? JAIDS J. Acquir. Immune Defic. Syndr. 2010, 54, 248-257. [CrossRef] [PubMed]

10. Buchacz, K.; Baker, R.K.; Moorman, A.C.; Richardson, J.T.; Wood, K.C.; Holmberg, S.D.; Brooks, J.T. Rates of Hospitalizations and Associated Diagnoses in a Large Multisite Cohort of HIV Patients in the United States, 1994-2005. AIDS 2008, 22, 1345-1354. [CrossRef]

11. Limper, A.H.; Offord, K.P.; Smith, T.F.; Martin, W.J. Pneumocystis CariniiPneumonia: Differences in Lung Parasite Number and Inflammation in Patients with and without AIDS. Am. Rev. Respir. Dis. 1989, 140, 1204-1209. [CrossRef]

12. Roux, A.; Canet, E.; Valade, S.; Gangneux-Robert, F.; Hamane, S.; Lafabrie, A.; Maubon, D.; Debourgogne, A.; Le Gal, S.; Dalle, F.; et al. Pneumocystis Jirovecii Pneumonia in Patients with or without AIDS, France. Emerg. Infect. Dis. 2014, 20, 1490-1497. [CrossRef] [PubMed]

13. Bienvenu, A.-L.; Traore, K.; Plekhanova, I.; Bouchrik, M.; Bossard, C.; Picot, S. Pneumocystis Pneumonia Suspected Cases in 604 Non-HIV and HIV Patients. Int. J. Infect. Dis. 2016, 46, 11-17. [CrossRef] [PubMed]

14. HCUP-US NIS Overview. Available online: https:/ / www.hcup-us.ahrq.gov/nisoverview.jsp (accessed on 14 January 2022).

15. NIS Trend Weights. Available online: https://www.hcup-us.ahrq.gov/db/nation/nis/trendwghts.jsp (accessed on 14 January 2022). 
16. HCUP Methods Series Calculating National Inpatient Sample (NIS) Variances for Data Years 2012 and Later. Available online: https:/ / www.hcup-us.ahrq.gov/reports/methods/2015_09.jsp (accessed on 14 January 2022).

17. Elixhauser Comorbidity Software, Version 3.7. Available online: https://www.hcup-us.ahrq.gov/toolssoftware/comorbidity/ comorbidity.jsp (accessed on 14 January 2022).

18. Khera, R.; Angraal, S.; Couch, T.; Welsh, J.W.; Nallamothu, B.K.; Girotra, S.; Chan, P.S.; Krumholz, H.M. Adherence to Methodological Standards in Research Using the National Inpatient Sample. JAMA 2017, 318, 2011. [CrossRef]

19. Kovacs, J.A.; Masur, H. Evolving Health Effects of Pneumocystis. JAMA 2009, 301, 2578. [CrossRef]

20. Variable Impact on Mortality of AIDS-Defining Events Diagnosed during Combination Antiretroviral Therapy: Not All AIDSDefining Conditions Are Created Equal. Clin. Infect. Dis. 2009, 48, 1138-1151. [CrossRef]

21. Walzer, P.D.; Evans, H.E.R.; Copas, A.J.; Edwards, S.G.; Grant, A.D.; Miller, R.F. Early Predictors of Mortality from Pneumocystis Jirovecii Pneumonia in HIV-Infected Patients: 1985-2006. Clin. Infect. Dis. 2008, 46, 625-633. [CrossRef] [PubMed]

22. Radhi, S.; Alexander, T.; Ukwu, M.; Saleh, S.; Morris, A. Outcome of HIV-Associated Pneumocystis Pneumonia in Hospitalized Patients from 2000 through 2003. BMC Infect. Dis. 2008, 8, 118. [CrossRef]

23. Fei, M.W.; Sant, C.A.; Kim, E.J.; Swartzman, A.; Davis, J.L.; Jarlsberg, L.G.; Huang, L. Severity and Outcomes of Pneumocystis Pneumonia in Patients Newly Diagnosed with HIV Infection: An Observational Cohort Study. Scand. J. Infect. Dis. 2009, 41, 672-678. [CrossRef] [PubMed]

24. Nakanjako, D.; Kiragga, A.N.; Musick, B.S.; Yiannoutsos, C.T.; Wools-Kaloustian, K.; Diero, L.; Oyaro, P.; Lugina, E.; Ssali, J.C.; Kambugu, A.; et al. Frequency and Impact of Suboptimal Immune Recovery on First-Line Antiretroviral Therapy within the International Epidemiologic Databases to Evaluate AIDS in East Africa. AIDS 2016, 30, 1913-1922. [CrossRef] [PubMed]

25. López-Sánchez, C.; Falcó, V.; Burgos, J.; Navarro, J.; Martín, M.T.; Curran, A.; Miguel, L.; Ocaña, I.; Ribera, E.; Crespo, M.; et al. Epidemiology and Long-Term Survival in HIV-Infected Patients with Pneumocystis Jirovecii Pneumonia in the HAART Era. Medicine 2015, 94, e681. [CrossRef] [PubMed]

26. Kaplan, J.E.; Hanson, D.; Dworkin, M.S.; Frederick, T.; Bertolli, J.; Lindegren, M.L.; Holmberg, S.; Jones, J.L. Epidemiology of Human Immunodeficiency Virus-Associated Opportunistic Infections in the United States in the Era of Highly Active Antiretroviral Therapy. Clin. Infect. Dis. 2000, 30 (Suppl. 1), S5-S14. [CrossRef] [PubMed]

27. Sepkowitz, K.A. Pneumocystis Carinii Pneumonia without Acquired Immunodeficiency Syndrome. More Patients, Same Risk. Arch. Intern. Med. 1995, 155, 1125-1128. [CrossRef]

28. Kamanfu, G.; Mlika-Cabanne, N.; Girard, P.-M.; Nimubona, S.; Mpfizi, B.; Cishako, A.; Roux, P.; Coulaud, J.-P.; Larouzé, B.; Aubry, P.; et al. Pulmonary Complications of Human Immunodeficiency Virus Infection in Bujumbura, Burundi. Am. Rev. Respir. Dis. 1993, 147, 658-663. [CrossRef] [PubMed]

29. Batungwanayo, J.; Taelman, H.; Dhote, R.; Bogaerts, J.; Allen, S.; van de Perre, P. Pulmonary Tuberculosis in Kigali, Rwanda: Impact of Human Immunodeficiency Virus Infection on Clinical and Radiographic Presentation. Am. Rev. Respir. Dis. 1992, 146, 53-58. [CrossRef] [PubMed]

30. Wasserman, S.; Engel, M.E.; Griesel, R.; Mendelson, M. Burden of Pneumocystis Pneumonia in HIV-Infected Adults in SubSaharan Africa: A Systematic Review and Meta-Analysis. BMC Infect. Dis. 2016, 16, 482. [CrossRef] [PubMed]

31. Fischi, M.A. Safety and Efficacy of Sulfamethoxazole and Trimethoprim Chemoprophylaxis for Pneumocystis Carinii Pneumonia in AIDS. JAMA 1988, 259, 1185. [CrossRef]

32. Schneider, M.M.E.; Hoepelman, A.I.M.; Schattenkerk, J.K.M.E.; Nielsen, T.L.; van der Graaf, Y.; Frissen, J.P.H.J.; van der Ende, I.M.E.; Kolsters, A.F.P.; Borleffs, J.C.C. A Controlled Trial of Aerosolized Pentamidine or Trimethoprim-Sulfamethoxazole as Primary Prophylaxis AgainstPneumocystis CariniiPneumonia in Patients with Human Immunodeficiency Virus Infection. $N$. Engl. J. Med. 1992, 327, 1836-1841. [CrossRef] [PubMed]

33. Hardy, W.D.; Feinberg, J.; Finkelstein, D.M.; Power, M.E.; He, W.; Kaczka, C.; Frame, P.T.; Holmes, M.; Waskin, H.; Fass, R.J.; et al. A Controlled Trial of Trimethoprim-Sulfamethoxazole or Aerosolized Pentamidine for Secondary Prophylaxis of Pneumocystis Carinii Pneumonia in Patients with the Acquired Immunodeficiency Syndrome. N. Engl. J. Med. 1992, 327, 1842-1848. [CrossRef]

34. Hanna, D.B.; Hessol, N.A.; Golub, E.T.; Cocohoba, J.M.; Cohen, M.H.; Levine, A.M.; Wilson, T.E.; Young, M.; Anastos, K.; Kaplan, R.C. Increase in Single-Tablet Regimen Use and Associated Improvements in Adherence-Related Outcomes in HIV-Infected Women. JAIDS J. Acquir. Immune Defic. Syndr. 2014, 65, 587-596. [CrossRef]

35. Mannheimer, S.B.; Wang, L.; Wilton, L.; Van Tieu, H.; del Rio, C.; Buchbinder, S.; Fields, S.; Glick, S.; Connor, M.B.; Cummings, V.; et al. Infrequent HIV Testing and Late HIV Diagnosis Are Common among a Cohort of Black Men Who Have Sex with Men in 6 US Cities. JAIDS J. Acquir. Immune Defic. Syndr. 2014, 67, 438-445. [CrossRef]

36. Dailey, A.F.; Hoots, B.E.; Hall, H.I.; Song, R.; Hayes, D.; Fulton, P.; Prejean, J.; Hernandez, A.L.; Koenig, L.J.; Valleroy, L.A. Vital Signs: Human Immunodeficiency Virus Testing and Diagnosis Delays-United States. MMWR. Morb. Mortal. Wkly. Rep. 2017, 66, 1300-1306. [CrossRef]

37. HIV Risk, Prevention, and Testing Behaviors Among Heterosexuals at Increased Risk for HIV Infection-National HIV Behavioral Surveillance System, 21 U.S. Cities. 2010. Available online: https://www.cdc.gov/mmwr/preview/mmwrhtml/ss6314a1.htm (accessed on 15 February 2022).

38. Centers for Disease Control and Prevention. HIV Surveillance Report; 2015; Volume 27, Published November 2016. Available online: http:/ / www.cdc.gov/hiv/library/reports/hiv-surveillance.html (accessed on 13 February 2022). 
39. Cohen, M.S.; Chen, Y.Q.; McCauley, M.; Gamble, T.; Hosseinipour, M.C.; Kumarasamy, N.; Hakim, J.G.; Kumwenda, J.; Grinsztejn, B.; Pilotto, J.H.S.; et al. Antiretroviral Therapy for the Prevention of HIV-1 Transmission. N. Engl. J. Med. 2016, 375, 830-839. [CrossRef]

40. Wu, L.; Zhang, Z.; Wang, Y.; Hao, Y.; Wang, F.; Gao, G.; Yang, D.; Xiao, J.; Zhao, H. A Model to Predict In-Hospital Mortality in HIV / AIDS Patients with Pneumocystis Pneumonia in China: The Clinical Practice in Real World. BioMed Res. Int. 2019, 2019, 6057028. [CrossRef] [PubMed]

41. Alvaro-Meca, A.; Palomares-Sancho, I.; Diaz, A.; Resino, R.; De Miguel, A.G.; Resino, S. Pneumocystis Pneumonia in HIV-Positive Patients in Spain: Epidemiology and Environmental Risk Factors. J. Int. AIDS Soc. 2015, 18, 19906. [CrossRef] [PubMed]

42. Wang, H.-W.; Lin, C.-C.; Kuo, C.-F.; Liu, C.-P.; Lee, C.-M. Mortality Predictors of Pneumocystis Jirovecii Pneumonia in Human Immunodeficiency Virus-Infected Patients at Presentation: Experience in a Tertiary Care Hospital of Northern Taiwan. J. Microbiol. Immunol. Infect. 2011, 44, 274-281. [CrossRef]

43. Sun, J.; Su, J.; Xie, Y.; Yin, M.T.; Huang, Y.; Xu, L.; Zhou, Q.; Zhu, B. Plasma IL-6/IL-10 Ratio and IL-8, LDH, and HBDH Level Predict the Severity and the Risk of Death in AIDS Patients WithPneumocystisPneumonia. J. Immunol. Res. 2016, 2016, 1583951. [CrossRef]

44. Cowell, A.; Shenoi, S.V.; Kyriakides, T.C.; Friedland, G.; Barakat, L.A. Trends in Hospital Deaths among Human Immunodeficiency Virus-Infected Patients during the Antiretroviral Therapy Era, 1995 to 2011. J. Hosp. Med. 2015, 10, 608-614. [CrossRef] [PubMed]

45. Kim, J.H.; Psevdos, G.; Gonzalez, E.; Singh, S.; Kilayko, M.C.; Sharp, V. All-Cause Mortality in Hospitalized HIV-Infected Patients at an Acute Tertiary Care Hospital with a Comprehensive Outpatient HIV Care Program in New York City in the Era of Highly Active Antiretroviral Therapy (HAART). Infection 2012, 41, 545-551. [CrossRef] [PubMed]

46. Huson, M.A.M.; Grobusch, M.P.; van der Poll, T. The Effect of HIV Infection on the Host Response to Bacterial Sepsis. Lancet Infect. Dis. 2015, 15, 95-108. [CrossRef]

47. Jordano, Q.; Falco, V.; Almirante, B.; Planes, A.M.; del Valle, O.; Ribera, E.; Len, O.; Pigrau, C.; Pahissa, A. Invasive Pneumococcal Disease in Patients Infected with HIV: Still a Threat in the Era of Highly Active Antiretroviral Therapy. Clin. Infect. Dis. 2004, 38, 1623-1628. [CrossRef]

48. Lombardi, F. Weekend Effect on Acute MI Mortality. Eur. Heart J. 2018, 39, 2698. [CrossRef]

49. Liu, L.; Hao, D.; Liu, W.; Wang, L.; Wang, X. Does Weekend Hospital Admission Affect Upper Gastrointestinal Hemorrhage Outcomes? J. Clin. Gastroenterol. 2020, 54, 55-62. [CrossRef]

50. Ananthakrishnan, A.N.; McGinley, E.L.; Saeian, K. Outcomes of Weekend Admissions for Upper Gastrointestinal Hemorrhage: A Nationwide Analysis. Clin. Gastroenterol. Hepatol. 2009, 7, 296-302. [CrossRef] [PubMed]

51. Gunasekaran, K.; Murthi, S.; Elango, K.; Rahi, M.S.; Thilagar, B.; Ramalingam, S.; Voruganti, D.; Paramasivam, V.K.; Kolandaivel, K.P.; Arora, A.; et al. The Impact of Diabetes Mellitus in Patients with Chronic Obstructive Pulmonary Disease (COPD) Hospitalization. J. Clin. Med. 2021, 10, 235. [CrossRef] [PubMed]

52. Gunasekaran, K.; Voruganti, D.C.; Singh Rahi, M.; Elango, K.; Ramalingam, S.; Geeti, A.; Kwon, J. Trends in Prevalence and Outcomes of Cannabis Use among Chronic Obstructive Pulmonary Disease Hospitalizations: A Nationwide Population-Based Study 2005-2014. Cannabis Cannabinoid Res. 2021, 6, 340-348. [CrossRef] [PubMed] 